\title{
GENETIC CHARACTERIZATION OF SOMATIC RECOMBINATION IN TRICHODERMA PSEUDOKONINGII
}

\author{
Fernando Gomes Barcellos; Aline Aparecida Pizzirani-Kleiner* \\ Departamento de Genética, Escola Superior de Agricultura “Luiz de Queiroz”, Universidade de São Paulo, \\ Piracicaba, SP, Brasil.
}

Submitted: July 10, 2002; Returned to authors for corrections: October 01, 2002; Approved: June 05, 2003

\begin{abstract}
Crossing experiments via hyphal anastomosis between two strains contrasting for auxotrophic markers of Trichoderma pseudokoningii were conducted to characterize the somatic recombination process in this specie. Four crossings were made and a total of 1052 colonies obtained from conidial suspensions of the heterokaryotic colonies were analyzed. Sixty-eight recombinant colonies, from four growing generations, were analyzed for the auxotrophic markers. Of the 68 colonies analyzed, 58 were stable after four generations and the remainders were unstable, reverting to one of the parentals. Most of the recombinant colonies were unstable through subculture and after four growing generations they showed the leu ino met markers (auxotrophic for leucin, inositol and metionin respectively). The unstable recombinant colonies showed irregular growing borders, sparse sporulation and frequent sector formation. The results suggest the occurrence of recombination mechanisms in the heterokaryon (somatic recombination), different from those described for the parasexual cycle or parameiosis. Therefore, we proposed the ocurrence of nuclei degradation from one parental (non prevalent parental) in the heterokaryon and that the resulting chromosomal fragments may be incorporated into whole nuclei of the another parental (prevalent parental). However the parameiosis as originally described cannot be excluded.
\end{abstract}

Key words: somatic recombination, heterokaryon, unstable recombinants, parameiosis

\section{INTRODUCTION}

The species of the Trichoderma are important producers of cellulolytic and hemicellulolytic enzymes. They are also used in the biological control of phytophatogens, mainly roots of many cultivated plants, in the biodegradation of chlorophenolic compounds and in soil bioremediation (2). Due to the importance of the species of this genera, it is necessary to obtain genetically improved strains that show desirable characteristics for commercial and industrial utilization. The majority of the species utilized were isolated directly from the environment, being some submitted to mutation-selection processes $(2,8)$. Thus, recombination processes to combine desirable characteristics and to optimize the use of genetic potential of the different isolated Trichoderma strains are need. In Trichoderma the sexual phase of reproduction has not been found. However it is known that the perfect phase of this fungus is related to ascomycetes species of Hypocrea, since many species of the genera, including Trichoderma pseudokoningii, were isolated from Hypocrea ascospores (8).

In many Trichoderma species, the obtainment of recombinants through somatic recombination processes, either by anastomosis or protoplast fusions, have been described. In most of these processes, common features were identified, such as the appearance of slow growing unstable recombinant colonies on selective media, with the frequent sector formation and showing the genetic markers from only one of the parents (12).

\footnotetext{
* Corresponding author. Mailing address: Departamento de Genética, ESALQ/USP, Av. Pádua Dias, 11. Caixa Postal 83. 13400-970, Piracicaba, SP, Brasil. Fax: (+5519) 3433-6706. E-mail: aapklein@esalq.usp.br
} 
The purpose of this research was to study the process of obtainment of recombinants (somatic recombination) in Trichoderma pseudokoningii for a better application of inter and intra-strain crossing methods in breeding programs of this specie.

\section{MATERIALS AND METHODS}

\section{Strains}

Two auxotrophic mutants of Trichoderma pseudokoningii were used as parentals: the mutant $9 \mathrm{~L}\left(\mathrm{leu}^{-}, \mathrm{lys}^{-}, \mathrm{met}^{-}, \mathrm{arg}^{-}\right)$and the mutant $12 \mathrm{~L}$ (nic ${ }^{-}$, met ${ }^{-}$, ino $^{-}$, leu$^{-}$) obtained by ultraviolet mutagenesis (4).

\section{Media}

Complete medium $(\mathrm{CM})$, minimal medium (MM) and minimal medium supplemented with required auxotroph markers as described by Pontecorvo et al. (7) were used.

\section{Heterokaryon formation via anastomosis}

Conidia from both parental strains were inoculated on liquid medium (MM) plus 4\% CM and mixed to give a final density of $10^{6} \mathrm{spores} / \mathrm{ml}$ for each auxotrophic mutant used. The mixed spore suspension was dropped onto a central well previously done in a solid agar (MM) petri dish and incubated at $28^{\circ} \mathrm{C}$ and after 7 days the heterokaryotic colonies were observed. With the exception of the third heterokaryon (Table 1) the heterokaryotic colonies were grown on MM supplemented with leucin (leu) and metionin (met) that are nutritional deficiency markers of both parental strains. The third heterokaryon was grown on MM without supplementation.

\section{Recombinant colonies isolation}

Conidia from heterokaryotic colonies were resuspended in tween $80(0.1 \%)$ solution, diluted in $\mathrm{NaCl}(0.2 \mathrm{M})$ solution and plated on CM and MM. These conidia suspensions were also plated on MM supplemented with the markers involved in the heterokaryon formation, always combining the parental auxotroph markers, minus one (a total of 6 media combining all markers minus one). The isolation on selective media (supplemented MM) is necessary to eliminate accelarated growth effects of some recombinant genotypes, mainly prototrophic colonies, that decrease the frequency of isolation of another recombinant genotypes of slow growth on non selective CM media. The prototrophic colonies were recovered on MM and the auxotrophic recombinant colonies were on selective media and CM. On the first heterokaryon (Table 1), the isolation of colonies was done only on non-selective media CM.

\section{Analyses of Progeny}

The colonies grown on $\mathrm{CM}$ and on selective media were transferred to CM master plates (with 26 inoculated points) and incubated for 5 days at $28^{\circ} \mathrm{C}$. The colonies were analyzed on MM, MM plus nutritional markers of the two parental strains and MM plus all nutritional markers minus that on analysis. The results of growth of each colony obtained in all selective media were noted and the recombinant or parental genotypes identified. The growth evaluations were made after two and three days of incubation. The evaluations were extended for until 7 days for those recombinants that showed a very slow growth on selective medium. The frequencies of recombinants were obtained considering the number of each type of recombinant and the total number of colonies analyzed.

\section{RESULTS AND DISCUSSION}

\section{Crossings and recombinant progeny analysis}

Two contrasting parental strains for auxotrophic markers (Fig. 1) were used in four crossings, and formed four heterokaryotic colonies (Table 1).

The heterokaryotic colonies presented fast growth and intense sporulation (Fig .1). Furlaneto and Pizzirani-Kleiner (3) obtained similar results in crossings using T. pseudokoningii auxotrophic mutant strains. The results are summarized in Table 1.
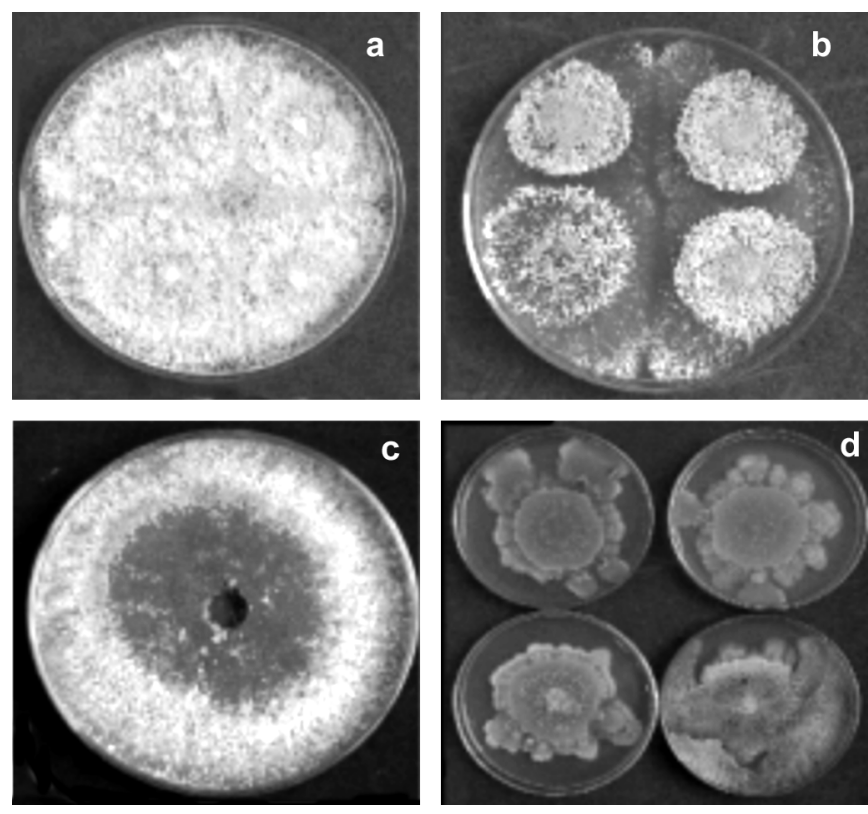

Figure 1: Growing aspects of T. pseudokoningii. (a) parental strain 9L (leu', lys ${ }^{-}$, met $\left.^{-}, \mathrm{arg}^{-}\right)$; (b) parental strain 12L (nic ${ }^{-}$, met, ino $^{-}$, leu $^{-}$); (c) a heterokaryotic colony obtained from the crossing between 9L and 12L strains; and (d) some unstable recombinant colonies, showing sparse sporulation and irregular growing borders with sectors formation. 
Table 1. Somatic recombination frequencies in the heterokaryons from crossings between 9L and 12L parental strains (number of recombinant colonies/total number of colonies analyzed).

\begin{tabular}{lccccc}
\hline & $\begin{array}{c}1^{\text {st }} \\
\text { Heterokaryon }\end{array}$ & $\begin{array}{c}2^{\text {nd }} \\
\text { Heterokaryon }\end{array}$ & $\begin{array}{c}3^{\text {rd }} \\
\text { Heterokaryon }\end{array}$ & $\begin{array}{c}4^{\text {th }} \\
\text { Heterokaryon }\end{array}$ & Total \\
\hline Recombinants: & & & & & \\
Prototrophs & 35 & 2 & 1 & 25 & 63 \\
Non prototrophs & 28 & 2 & 1 & 17 & 48 \\
Total & $63(14.3 \%)$ & $4(2 \%)$ & $2(2.5 \%)$ & $42(12.5 \%)$ & $111(10.5 \%)$ \\
Parental strains: & & & & & \\
9L strain & 27 & 196 & 0 & 294 & 517 \\
12L strain & 348 & 0 & 76 & 0 & 424 \\
Total & $375(85.6 \%)$ & $196(98 \%)$ & $76(97.4 \%)$ & $294(87.5 \%)$ & $941(89.4 \%)$ \\
\hline Total & 438 & 200 & 78 & 336 & 1052 \\
\hline
\end{tabular}

In relation to the media utilized for colonies isolation from the heterokaryon, it was verified that the use of CM in the first heterokaryon increased the number of colonies recovered and the proportion of recombinant colonies obtained was not decreased (Table 1). The use of MM for the formation of the third heterokaryon, without supplementation of leucin $(l e u)$ and metionin (met) that are nutritional deficiency markers of both parental strains, caused a drastically decrease on the number of colonies obtained on selective media and the proportion of recombinants (Table 1). Due to the growth of the third heterokaryon on MM, probably the two parental strains own mutations in different genes of the metabolic pathway of synthesis of leucin and methionin. Thus, these nutritional deficiencies were complemented in the mycelium of the heterokaryon. However, the growth rate of the third heterokaryon was lower than the others heterokaryotic colonies (data not shown).

A thousand and fifty two colonies were isolated from all heterokaryons. A total of 111 recombinant colonies (10\%) were initially obtained (Table 1).

At the parental colonies isolation, a prevalence of only one of the parental genotypes was observed, where in each heterokaryon analyzed the prevalent parental was changed (Table 1). The prevalence of one of the parental genotypes was total with the exception of the first heterokaryon.

To confirm the tendency of predominant recovery of one of the parentals in the progenies obtained from the heterokaryons, a new heterokaryon was made as described previously. A conidial suspension was obtained from this new heterokaryon, then appropriately diluted and inoculated on $\mathrm{CM}$. The parental phenotypes proportions were analyzed through observation of colony morphology. These observations demonstrated a higher frequency of one of the parental genotypes, in this case the $12 \mathrm{~L}$ parental, with a frequency of $82 \%$. Here, the prevalence of $12 \mathrm{~L}$ genotype was not absolute as observed in the previously described heterokaryons. Furlaneto and Pizzirani-Kleiner (3) obtained heterokaryotic colonies from protoplast fusions between $T$. pseudokoningii strains, which originated sectors where the auxotroph markers were from only one of the parentals involved in the crossings. Stasz and Harman (12) analyzed the progenies originated from protoplast fusions between strains of several species of Trichoderma and verified that the majority of them showed the isozyme banding pattern invariably identical to one or the other parental strains.

On selective media, many recombinant colonies showed very slow growth and weak sporulation (Fig. 1), requiring from 15 to 30 days to form colonies of some millimeters of width. Also these colonies presented irregular borders and a frequent sector formation (Fig. 1). Pecchia and Anné (5) observed a slow development of progenies from crossings between strains of Trichoderma harzianum on selective medium. Stasz and Harman (12) studied progenies obtained from many crossings involving different strains from different species of Trichoderma and also observed a very slow development of the recombinant colonies on selective media. Several studies of crossings between strains, within specie or between different species of Trichoderma, through hyphal anastomosis, protoplast fusion or transfer of isolated nuclei into protoplasts, have described the obtainment of unstable recombinants colonies of slow growth on selective media, and with a frequent sector formation $(1,3,5,9,10,11,12)$.

Due to the unstable characteristic of the colonies initially isolated (single-conidial isolates) new subcultures were obtained in three generations of subcultures (two generations by single-conidial isolates). Thus, the auxotroph markers of the recombinant colonies were analyzed in four generations (data not shown). After the third generation of growth, among 68 recombinant colonies analyzed, 58 (5.51\% of the total colonies analyzed) kept the recombinant markers and 10 reverted to 
parental 9L. Of the 58 recombinant colonies, 7 were prototrophs and 51 presented the leu ino met markers (Table 2).

Some authors have described instability after subculture in generations of recombinant colonies obtained from crossings $(6,8,10,11,12)$. In some of these analyses, where the original obtained recombinants were submitted to subcultures, many reverted to one of the parental strains and others continued generating new variants. However, when these recombinants were analyzed using molecular markers, all were identical to only one of the parental strains involved in the crossings.

Table 2: Auxotroph markers showed by the recombinants colonies after four generations of subculture.

\begin{tabular}{cc}
\hline Progeny & Number of colonies \\
\hline Auxotroph markers & 51 \\
(leu- ino met) & \\
& \\
Prototrophs & 7 \\
Reverted to & 10 \\
parental genotype & (9L parental strain genotype) \\
\hline Total & 68 \\
\hline
\end{tabular}

All recombinant colonies obtained here were morphologically similar to parental $12 \mathrm{~L}$ and most of them had the leu ino met auxotroph markers where the ino marker was from the parental $12 \mathrm{~L}$.

The characteristics of the recombinant progeny, the instability through subcultures and the similarity to only one of the two parental strains suggest that a mechanism of somatic recombination, other than parasexuality, including parameiosis, may be occurring. Such mechanism of somatic recombination may be similar that proposed by Stasz and Harman (12), who suggested a new mechanism based on comparable results obtained from crossings involving species of Trichoderma harzianum, T. hamatum, T. koningii and $T$. viride. According to these authors nuclei of the nonprevalent parent may be degraded in the heterokaryon, and small portions of this genome may be incorporated into the genome of the prevalent parent. This mechanism of somatic recombination may explain the pattern of recombinants obtained here, but the parameiosis as originally described can not be discarded.

\section{ACKNOWLEDGEMENTS}

This work was supported by CNPq agency. The authors would like to thank Luciana Cursino and Ricardo Yara for their critical reading of the manuscript and helpful comments.

\section{RESUMO}

\section{Caracterização genética da recombinação somática em Trichoderma pseudokoningii}

Com o objetivo de se caracterizar o processo de recombinação somática em Trichoderma pseudokoningii, foram realizados cruzamentos via anastomose de hifas entre duas linhagens desta espécie, contrastantes para os marcadores de auxotrofia. Foram realizados quatro cruzamentos, sendo analisadas um total de 1052 colônias obtidas a partir de suspensões de conídios provenientes das colônias heterocarióticas. Foram analisadas sessenta e oito colônias recombinantes em quatro gerações de crescimento, sendo verificados os marcadores de auxotrofia. Das 68 colônias, 58 se mostraram estáveis após quatro gerações de crescimento e as colônias restantes permaneceram instáveis, revertendo para as marcas de uma das linhagens parentais. A maioria das colônias se mostrou instável através das gerações de subcultivo, e após quatro gerações de crescimento estas apresentaram as marcas de auxotrofia leu ino met (auxotrofia para leucina, inositol e metionina, respectivamente). As colônias recombinantes instáveis apresentaram bordas irregulares de crescimento, esporulação esparsa e a frequiente formação de setores. Os resultados sugerem a ocorrência de mecanismos de recombinação no heterocário (recombinação somática), diferente daqueles descritos para o ciclo parassexual ou parameiose, sendo proposto a ocorrência da degradação no heterocário de núcleos provenientes de uma das linhagens parentais (parental não prevalente) e a incorporação de fragmentos cromossômicos nos núcleos íntegros da outra linhagem parental (parental prevalente). No entanto a parameiose, como originalmente descrita, não pode ser excluída.

Palavras-chave: recombinação somática, heterocário, recombinantes instáveis, parameiose

\section{REFERENCES}

1. Bagagli, E.; Furlaneto, M.C.; Pizzirani-Kleiner, A.; Azevedo, J.L. Genetic recombinants in Trichoderma pseudokoningii (Rifai) without typical parasexuality. Can. J. of Microbiol., 41: 11321134, 1995

2. Esposito, E.; Silva, M. Systematics and environmental application of the genus Trichoderma. Crit. Rev. Microbiol., 24(2): 89-98, 1998.

3. Furlaneto, M.C.; Pizzirani-Kleiner, A.A. Intraspecific hybridization of Trichoderma pseudokoningii by anastomosis and protoplasts fusion. FEMS Microbiol. lett., 90: 191-196, 1992.

4. Nadalini, M.F.C. Caracterização genética e produção de celulases em Trichoderma pseudokoningii. Rio Claro, 1997. 142p. (Ph.D. Thesis. Instituto de Biociências do Campus de Rio Claro, Universidade Estadual Paulista).

5. Pecchia, S.; Anné, J. Fusion of protoplast from antagonistic Trichoderma harzianum strains. Act. Hortic., 255: 303-311, 1989. 
6. Pe'er, S.; Chet, I. Trichoderma protoplast fusion: a tool for improving biocontrol agents. Can. J. microbiol., 36: 6-9, 1990.

7. Pontecorvo, G.; Roper, J.A.; Forbes, E. Genetic recombination without sexual reproduction in Aspergillus niger. J. Gen. Microbiol., v. 8: 198-210, 1953.

8. Samuels, G.J. Trichoderma: a review of biology and systematics of the genus. Mycol. Res., 100(8): 923-935, 1996.

9. Sivan, A.; Harman, G.E.; Stasz, T.E. Transfer of isolated nuclei into protoplasts of Trichoderma harzianum. Appl. Environ. Microbiol., 56: 2404-2409, 1990.
10. Stasz, T.E.; Harman, G.E.; Weeden, N.F. Protoplast preparation and fusion in two biocontrol strains of Trichoderma harzianum. Mycologia, 80(2): 141-150, 1988.

11. Stasz, T.E.; Harman, G.E.; Gullino, M.L. Limited vegetative compatibility following intra and interspecific protoplast fusion in Trichoderma. Exp. Mycol., 13: 364-371, 1989.

12. Stasz, T.E.; Harman, G.E. Nonparental progeny resulting from protoplast fusion in Trichoderma in the absence of parassexuality. Exp. Mycol., 14: 145-159, 1990. 